\title{
Musik och politik - på vilket sätt är en politisk blåsorkester politisk?
}

\author{
Recension av Bengt Hall (red.), Röda Kapellet - bläsorkester med \\ hjärtat till vänster (Arkiv förlag och Röda Kapellet, Lund 20I4) \\ \& Hans Jeleby, Karin Spinetti, Thomas Svensson \& Cecilia Torudd \\ (red.), Blåsorkestern - 40 år i politikens och musikens tjänst \\ (Bokförläggarna Röda Rummet, Stockholm 2016) \\ CHRISTIAN ANDERSSON (F.D. ALTSAX)
}

En blåsorkester är en orkester som består av blåsinstrument och slagverk. Träblåsinstrument som ingår är flöjt, oboe, klarinett, saxofon och fagott. Brassinstrumenten är trumpet, horn, trombon, eufonium och tuba. En vanlig blåsorkester består ofta av omkring trettio till femtio musikanter. [...] I Sverige finns ca 200 blåsorkestrar på ideell bas och sju professionella, där fyra av dessa [...] spelar blåsorkester på heltid. ${ }^{1}$

Två svenska blåsorkestrar har nyligen firat sina 40-årsjubileer, två av de ca 200 i Sverige som blåser mer eller mindre regelbundet och mer eller mindre ideellt. Det är Röda Kapellet i Lund som startade i samband med dåvarande Vänsterpartiet kommunisternas förstamajdemonstration i Lund 1974 och Vänsterns blåsorkester i Stockholm som uppstod på VPK:s bokcafé i Nacka 1976. I samband med jubileerna har båda orkestrarna gett ut var sin festskrift, Röda Kapellet - blåsorkester med hjärtat till vänster och Blåsorkestern - 40 år i politikens och musikens tjänst. Den senare bär dessutom den storslagna undertiteln Historien om en orkester som sedan 1976 berikat Stockholms kulturliv.

Jubileumsskrifter publiceras i allmänhet för de närmast berörda. Man vill känna igen namn och händelser i bild och text, frossa i minnen och nostalgi. Det finns onekligen mycket av detta i de båda skrifterna, särskilt hos Stockholmsorkestern. Däremot är de båda skrifterna mer sparsmakade

I. Från Wikipedia, uppslagsordet blåsorkester: https://sv.wikipedia.org/wiki/Blåsorkester, hämtat 13 november 2017 . 
när det gäller att diskutera en politisk orkesters mer existentiella frågor. Vari består egentligen det politiska? Lundaorkestern ger de frågorna något mer utrymme.

För att förenkla en aning kan man väl säga att det politiska kan ligga på två plan: dels på det institutionella planet och dels på det musikaliska. Är orkestern politisk på grund av organisatorisk anknytning till politisk rörelse, i det här fallet inom den politiska vänstern? Är orkestern politisk eftersom den har en repertoar som kan associeras med socialistiska idéer och praktiker? Eftersom det primärt handlar om orkestermusik kan man inte falla tillbaka på text och ord utan måste förlita sig på lyssnarnas känslomässiga referenser och associationer.

Båda orkestrarna uppstod alltså som VPK-projekt. Lundaorkestern hette fram till 1989 Lunds kommunistiska blåsorkester. ”Det var aldrig något formellt antaget namn men det smög sig på", heter det i festskriften från 20I4. Tanken bakom namnet var "ekumenisk", alltså att också partilösa och kommunister utanför VPK skulle kunna ansluta sig, typ bokstavsvänstern. Men det fanns tydliga gränser: "Det får inte bli så att alla tromboner befinner sig i händerna på medlemmar av KFML(r)", varnar initiativtagarna i ett urdokument, som återges i faksimil. En detalj i dokumentet som kan chocka en och annan kalenderbitare är att det också framgår att Lundaorkestern egentligen inte startade förrän hösten 1975. Har man firat 40-årsjubileet ett år för tidigt? Tanken svindlar.

När kommunistregimerna i Öst- och Centraleuropa (realsocialismen) föll ihop och VPK strök k:et uppstod en namndiskussion i Lund. Många namnförslag lanserades, vissa mer eller mindre spexartade (till exempel Sandins sandaler eftersom orkestereldsjälen Gunnar Sandin gick omkring i sandaler året runt). Till slut stannade man för Röda Kapellet efter antinazistiska motståndsgrupper under andra världskriget eller, kanske, efter det göteborgska proggband som låg på Svensktoppen i början på 70-talet.

Författarna till jubileumskriften från Lund tycks ha känt behov av att snabbt gå förbi orkesterns första femton år under kommunistisk flagg: "Lundaorkestern har inte som systerorkestern i Stockholm känt samma bundenhet till Vänsterpartiet. Även om Röda Kapellet är en politisk orkester har man aldrig uppfattat sig som en partiorkester, kanske med 
undantag för de allra första åren.” I Stockholmsorkesterns jubileumsskrift från 2016 ges en annan bild. Lundaorkestern kallas genomgående "Lunds Kommunistiska Blåsorkester". Det enda stället där Röda Kapellet nämns i Stockholmsskriften är i listan över gratulanter, det vill säga där Lundaorkestern själv formulerat sitt namn. Man anar en viss syskonrivalitet.

Också Stockholmsorkestern har haft namnbekymmer. Efter inledande oklarheter tog sig orkestern namnet Hammaren och Skäran efter den klassiska sovjetiska symbolen, som också fanns i en rad västeuropeiska kommunistpartiers emblem, inklusive i partisymbolen för det starkt EU-vänliga italienska kommunistpartiet PCI. Det var för övrigt just till Italien och det italienska kommunistpartiets Unitá-fester som Stockholmsorkestern gjorde sin första utlandsresa sommaren 1984. Man tryckte upp T-tröjor med den gula hammaren och skäran mot bakgrund av en erigerad illröd tuba.

Hammaren och Skäran fick aldrig riktigt genomslag. En del illvilliga personer gjorde sig lustiga över att orkestern sällan kunde mobilisera den breda besättning som skulle ha behövts för att matcha de storslagna politiska parollerna och storstadsbullret. Bristen på tungt bleck var ibland både iögon- och iöronfallande. De illvilliga talade om "Hammaren och Skärvan”. Om detta står det ingenting i jubileumsskriften, men jag vet, för jag var med. I historiken skriver Lennart Kjörling och Torbjörn Tännsjö att namnfrågan blev akut när den sovjetiska ubåten U-I37 gick på grund i Blekinge skärgård 198I och den sovjetiska fanan med hammaren och skäran vajade över vattnet. Efter lång diskussion beslöt man att ge upp namnet utan att egentligen hitta något nytt. Orkestern heter numera Vänsterns blåsorkester "... men inte till följd av något beslut om saken. Det har bara blivit så”, skriver de båda författarna.

På samma sida ger Cecilia Torudd en kompletterande version av namnfrågan. Från februari 1982 kallade sig orkestern enligt Torudd för "VPK:s blåsorkester i Stockholm". Efter några år blossade namndiskussionen upp på nytt: "Men vi var några som tyckte oss ha fått mandat att börja kalla oss Blåsorkestern rätt och slätt”, skriver Torudd som också ritat en betydligt mer avspänd och självironisk logga än den gamla kommunistiska symbolen: en klarinettist som hukar sig med 
ryggen mot det piskande regnet. Vädrets makter stoppar inte Blåsorkestern! Rubriken på inbjudan till Stockholmsorkesterns jubileum på ABF-huset i Stockholm i oktober 2016 lyder dock: "Vänsterns blåsorkester firar sina första 40 år”.

Cecilia Torudd har också bidragit med kapitlet "Musik och politik" i Stockholmsorkesterns skrift. Det består huvudsakligen av citat från ett seminarium på ABF-huset i Stockholm i början av 2016 med Torbjörn Tännsjö, Göran Greider och Dror Feiler och ett 50-tal intresserade ("Endast enstaka inslag av folk under 6o", skriver Torudd). Seminariets tema var just "Blåsmusik och politik". Tyvärr gör formen med enbart citat ur inläggen att det blir svårt för läsaren att få något grepp om diskussionen. Greider säger i alla fall: "När ni tutar igång är det som om en hel bruksorkester från förra århundradet har vaknat till liv. Det är nästan skräckinjagande.” Från skärva till skräckinjagande - inte illa marscherat på 40 år.

Lundaorkestern ägnar frågan om politisk musik mer utrymme. Att analysera repertoaren litet mer teoretiskt ligger kanske närmare till hands för "Sveriges professorstätaste orkester". Hur som helst, båda orkestrarnas repertoar har breddats otroligt mycket sedan starten för 40 år sedan. Då bestod den av en kärna av några tiotal arbetar- och solidaritetssånger i enkla arrangemang av Lundadirigenten Bo Fagerström. Det var lättspelade arrangemang som gjorde att det gick att få kontinuitet i en orkester som aldrig kunde veta exakt vilken besättning man skulle kunna ställa upp med vid nästa spelning. Det gällde både i Lund och i Stockholm under de första åren.

$\mathrm{Nu}$ ståtar Lundaorkestern enligt egna uppgifter med en repertoar på 600 arrangemang och Stockholmsorkestern med 450. De gamla kampmelodierna har blivit relikter som förlorat mening och betydelse för de flesta lyssnare. Hur många vet att La Lega sjöngs av arbeterskorna på risfälten i norra Italien i slutet på I80o-talet som en uppmaning till facklig kamp? I dag finns en annan lega i norra Italien, Lega Nord, som står för högerpopulism och främlingsfientlighet. Och Venceremos - "Vi ska segra!" - hur många vet att Víctor Jara skrev texten för Salvador Allendes valkampanj i Chile 1970? Allende störtades i en blodig militärkupp den II september (det var vårt II september) 1973. Stockholmsorkestern spe- 
lade Venceremos på demonstrationerna utanför Chiles ambassad på årsdagen under 70-talet medan de chilenska flyktingarna ropade "nej, nej, inte den!" Venceremos var en segersång, inte en sång för känslor av hat och förtvivlan inför en diktatur som kom att bestå i sjutton år. Politisk musik lever som sagt genom associationer och känslor.

På sin jubileumskonsert på ABF-huset i Stockholm den 29 oktober 2016 spelade Stockholmsorkestern både La Lega och Venceremos. Pliktskyldigt, kanske. I övrigt bestod repertoaren av mer apolitiska stycken, inklusive en EU-hymn i smaskigt klezmerarrangemang av orkesterns mångårige ledare Jonas Forsell. Båda orkestrarnas musik har helt enkelt blivit mindre kampfylld och mer underhållande och det är nog lyckligt ur många aspekter. Det låter betydligt bättre och musiken kan nå en betydligt bredare publik utan pekpinne. Var sak har sin tid.

Om Lundaorkesterns jubileumsskrift kniper poäng i analys så vinner Stockholmsorkesterns skrift i estetik, mycket tack vare smartare layout och Cecilia Torudds teckningar. Uppenbart är att båda orkestrarna kan visa upp både förändring och kontinuitet under sina 40 år. Positionerna på den politiska vänsterfronten kvarstår även om båda orkestrarna brottats med namnfrågan och med de formella banden till det politiska partiet. De stora förändringarna är musikaliska. Jubileumskonserten på ABF-huset fick en mäktig avslutning när orkestern gick från kampmusik till finstämda ackord som bakgrund till Jenny Wrangborgs läsning av tre dikter ur sin diktsamling Kallskänken (20IO). Konserten tonade ut i ett hoppfullt ”Jag är människa”. 


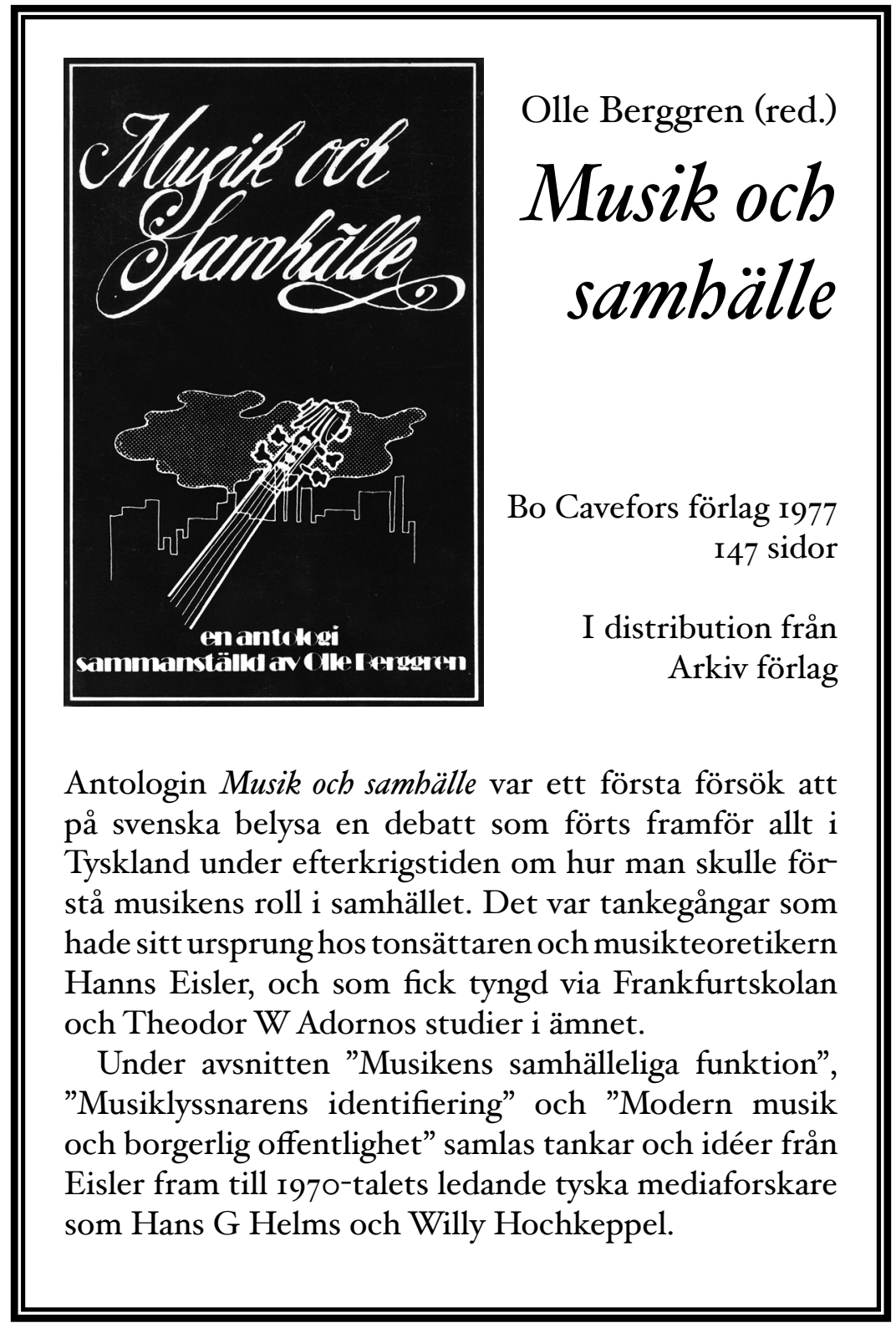

»Läs mer om boken på www.arkiv.nu» 